\title{
COMPARISON OF THE QUALITY OF DIFFERENT SPEAR SEGMENTS OF ASPARAGUS (ASPARAGUS OFFICINALIS L.) REARED IN LITHUANIA
}

Audronė ŽEBRAUSKIENĖ, Institute of Agricultural and Food Sciences, Faculty of Agronomy, Aleksandras Stulginskis University, Studentu str. 11, Akademija, Kaunas distr., Lithuania; audrone.zebrauskiene@asu.lt (coresponding author)

Sonata KAZLAUSKAITE், Institute of Biology and Plant Biotechnology, Faculty of Agronomy, Aleksandras Stulginskis University, Studentu str. 11, Akademija, Kaunas distr., Lithuania; sonata.kazlauskaite@ asu.lt

Ilona VAGUSEVIČIENĖ, Institute of Agricultural and Food Sciences, Faculty of Agronomy, Aleksandras Stulginskis University, Studentu str. 11, Akademija, Kaunas distr., Lithuania; ilona.vaguseviciene@asu.lt

Aurelija PAULAUSKIENE, Institute of Agricultural and Food Sciences, Faculty of Agronomy, Aleksandras Stulginskis University, Studentu str. 11, Akademija, Kaunas distr., Lithuania; aurelija.paulauskiene@asu.lt

\begin{abstract}
The studies on chemical composition of different parts of asparagus spears were carried out in 2013-2014 at the Institute of Agricultural and Food Sciences at Aleksandras Stulginskis University. Spears of two asparagus varieties ,Avalim` and ,Gijnlim ' were explored. Spears of $15 \mathrm{~cm}$ in length and $1 \mathrm{~cm}$ in diameter were selected and divided into three segments of $5 \mathrm{~cm}$ in length, i.e. spears were divided into three parts - upper, middle and lower. Chemical composition of fresh parts of asparagus spears (dry matter, vitamin C, potassium, nitrate, protein and fibre contents) was determined in the Laboratory of the Quality of Plant Raw Materials at ASU applying standardized analysis methods. Strength and hardness of spears was tested by texture analyser TA.XT Plus. Data of the research were statistically processed using STAT program from the statistical analysis package „SELEKCIJA“. Arithmetic means and standard deviations of the data were calculated.

The studies showed that the highest contents of vitamin C, dry matter, potassium and protein and the lowest nitrate content were determined in the upper part of asparagus spears. The largest content of fibre was found in the lower part of asparagus spears. The maximal hardness and elasticity were defined in the lower part of the spears as well.
\end{abstract}

Keywords: asparagus (Asparagus officinalis L.), spear segments, spears chemical composition, spear strength, spear hardness.

\section{INTRODUCTION}

Fresh vegetables are one of the main sources of minerals, vitamins and gastro-intestinal fibre. Vital compounds vitamins are found in fresh vegetables. About $90 \%$ of vitamin C is supplied by this way. Vegetables are rich with B-group vitamins (Januškevičius, Vaičiulienè et al., 2005). Mostly fresh vegetables (70-80\% of the annual amount) are consumed in late summer and autumn. Especially they are lacking in the second half of the winter and in the spring. During the spring period, this deficiency can be supplemented by fresh asparagus spears (Miao et al., 2012).

Asparagus (Asparagus officinalis L.) is a plant grown all over the world. In some countries of Western Europe, asparagus has been cultivated for some centuries as a valuable, nutritious delicacy (Maeda et al., 2005). More than $90 \%$ of water, $1.9 \%$ of proteins, $2.04 \%$ of carbohydrates, $1.31 \%$ of fibre, $0.16 \%$ of fat comprise spears of the plant. The vegetable contain $1.3 \mathrm{mg} \%$ of carotene, 0.14 to $0.19 \mathrm{mg} \%$ of B vitamins, and $40 \mathrm{mg} \%$ of vitamin C as well. Spears are rich in vitamin $\mathrm{E}$, one serving of spears supplies the full daily requirement of this vitamin. Asparagus spears are recognised as a source of vitamins A and B. They are rich in folic acid, potassium, iron, zinc, etc. Folic acid is involved in the production of red blood cells and is a strong diuretic. Their value is increased by saponins, capsanthin (Chin, Garrison, 2008, Oberbeil, Lentz, 2000; Shalaby, 2004). Results of the research have shown that asparagus spears accumulate more sugars, vitamin C, carotenoids, and less nitrates (Kmitienè et al., 2005, 2007; Žebrauskienè et al., 2013). Among 20 different amino acids which are detected in the composition of spears, asparagine is the most affluent. Asparagine is esential for ammonia metabolism, i.e. it is able to reduce the amount of ammonia in the human body. Asparagine has a blood pressure lowering effect, removes harmful substances from the body that accumulate in the joints. Tryptophan is an essential amino acid that is not synthesized in the organism, thus it is necessary to get it with a food (Weihua, Meijun et al., 2011).

Asparagus is a seasonal vegetable of high value. Texture is a key parameter in the quality of fresh, canned or frozen spears. Any indications of woody texture unacceptable for the highest quality spears. For the first sort of asparagus spears

Copyright (C) 2017 The Authors. Published by Aleksandras Stulginskis University. This is an open-access article distributed under the terms of the Creative Commons Attribution License (CC-BY 4.0), which permits unrestricted use, distribution, and reproduction in any medium, provided the original author and source are credited. 
some indications of woody texture in the lower part of the spear is allowed, if the consumer can remove this blemish by peeling. Spears of the second sort may be slightly woody (Viškelis et al., 2003).

According to the scientists, more mineral substances accumulate in the upper part of the asparagus spear comparing with the other parts of the vegetable (Makus, 1994). Rodkiewicz (2008) states that the amount of vitamin C in the upper part of the asparagus spear is approximately in 50\% higher than in the lower part.

The aim of the study was to determine and compare the quality of different parts of fresh asparagus spears.

\section{MATERIALS AND METHODS}

Two garden asparagus (Asparagus officinalis L.) hybrid varieties grown in the pomological garden of Aleksandras Stulginskis University were used for the research: ,Avalim' and ,Gijnlim'.

'Avalim' - 100 percent male hybrid, suitable for both bleached and green spears in the temperate climate zone. Three-quarters of the spears grow in a diameter of 16-28 mm, with a good taste. The spears of this variety are dark green, the stems are firm, non-lodging.

'Gijnlim' - 100 percent male hybrid, suitable for both bleached and green spears in the temperate climate zone. The variety is very early, characterized by exceptional productivity. Most of the spears are 16-24 mm in diameter, the scales are adherent. Spears are straight, intense colour. In the suitable soil, the diameter of the spears remains the same until the end of the harvesting season.

The harvested test material was immediately cooled with cold running water. For the study spears of $15 \mathrm{~cm}$ in length and $1 \mathrm{~cm}$ in diameter were selected and divided into three segments of $5 \mathrm{~cm}$ in length, i.e. divided into three parts: upper, middle and lower. Chemical composition of fresh parts of asparagus spears (dry matter, vitamin C, potassium, nitrate, protein and fibre contents) was determined in the Laboratory of the Quality of Plant Raw Materials at Aleksandras Stulginskis University applying standardized analysis methods. Three replications of $0.5 \mathrm{~kg}$ of asparagus spears for chemical analysis were taken.

Dry matter content was determined by drying the sample to constant weight at $105^{\circ} \mathrm{C}$ (LST ISO 751:2000).

Vitamin C content was assessed by the Murri method (LST ISO 6557-2:2000).

Potassium content was tested by ionometric method using an electrode (LST EN 12014-1 + A1:2001).

Nitrate content was found by ionometric method using an electrode (LST EN 12014-1 + A1:2001).

Fibre content was evaluated by intermediate filtration method (LST EN ISO 6865: 2001).

The protein content was determined by the Kjeldahl method (Januševičius, Mikulionienè, 2004).

Strength and hardness of spears were tested by texture analyser TA.XT Plus, Stable Micro Systems (UK). Probe of $0.79 \mathrm{~mm}$ diameter with a pointed tip was used for spears piercing. For analysis, 5 spears of each variant were taken.

Data of the research were statistically processed using STAT program from the statistical analysis package „SELEKCIJA“ (Tarakanovas, Raudonius, 2003). Arithmetic means and standard deviations of the data were calculated.

\section{RESULTS OF THE RESEARCH}

Analysis of the study data showed that vitamin $\mathrm{C}$ was concentrated in the upper part of the spear. $181.1 \mathrm{mg} \mathrm{kg}^{-1}$ of the vitamin have been determined in 'Avalim' spears and $192.1 \mathrm{mg} \mathrm{kg}^{-1}$ in 'Gijnlim'. These findings were nearly twice higher comparing with the vitamin $\mathrm{C}$ content detected in other parts of the asparagus spears. The lowest quantities of vitamin $\mathrm{C}$ were determined in the lower part of the spears. It was $83.0 \mathrm{mg} \mathrm{kg}^{-1}$ in 'Avalim', and $106.8 \mathrm{mg} \mathrm{kg}^{-1}$ in 'Gijnlim' (Fig. 1).

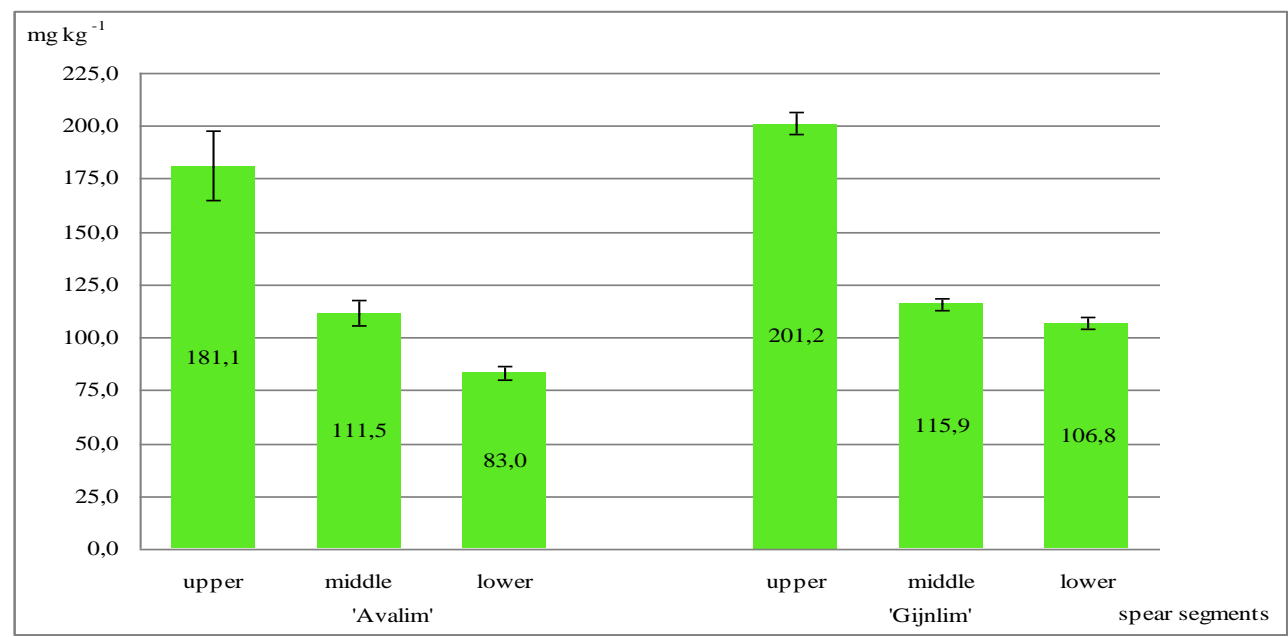

Figure 1. Vitamin C content in different parts of asparagus spears, 2013-2014.

Like vitamin $\mathrm{C}$ content, the highest amount of the dry matter has been accumulated in the upper part of the spears. 'Avalim' built up 7.2\%, and 'Gijnlim' 9.6\% of the dry matter. The lowest dry matter content has been recorded in the middle part of 'Avalim' spears - 6.4\%. While spears of the variety 'Gijnlim' the lowest dry matter content (6.8\%) had in the lower part (Fig. 2). 


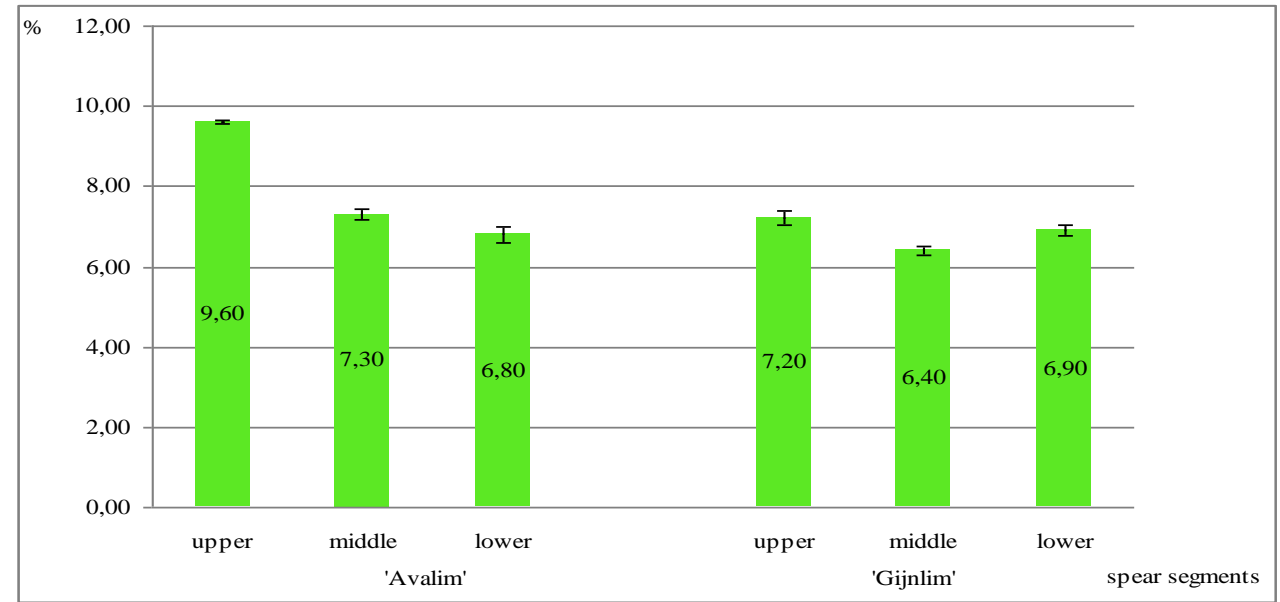

Figure 2. Dry matter content in different parts of asparagus spears, 2013-2014.

The highest amount of potassium (1698.2 $\left.\mathrm{mg} \mathrm{kg}^{-1}\right)$ was determined in the upper part of the variety 'Gijnlim' spears, and the lowest (1136.8 mg kg-1) in the lower part of the variety 'Avalim' spears (Fig. 3). Comparing the content of potassium in the spears of both tested asparagus varieties, it is evident that, the potassium content was higher in 'Gijnlim' spears.

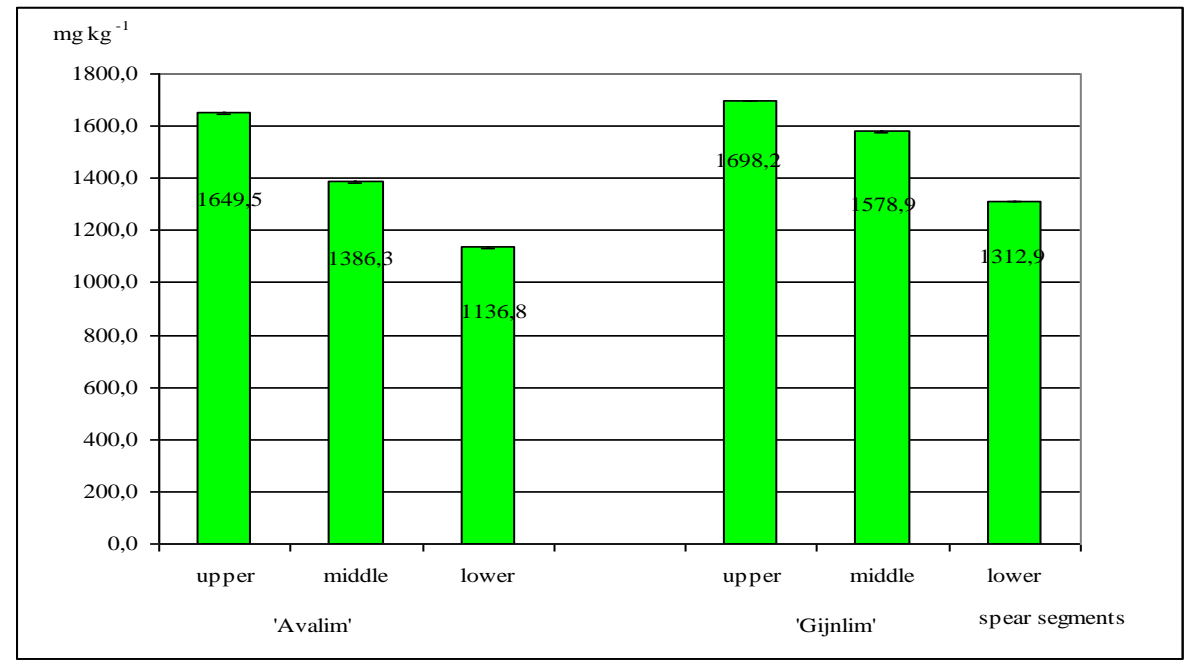

Figure 3. Potassium content in different parts of asparagus spears, 2013-2014.

The nitrate content in asparagus spears varied from $100.5 \mathrm{mg} \mathrm{kg}^{-1}$ up to $175.6 \mathrm{mg} \mathrm{kg}^{-1}$ (Fig. 4). During the study, the least nitrate content was determined in the upper part of the variety 'Avalim' spears $\left(100.5 \mathrm{mg} \mathrm{kg}^{-1}\right)$, and in the upper part of the variety 'Gijnlim' spears $\left(104.8 \mathrm{mg} \mathrm{kg}^{-1}\right)$ as well. The highest nitrate content $\left(175.6 \mathrm{mg} \mathrm{kg}^{-1}\right)$ was found in the lower part of the variety 'Gijnlim' spears. Asparagus spears of the variety 'Avalim' cumulated less nitrate amounts than spears of the variety 'Gijnlim'.

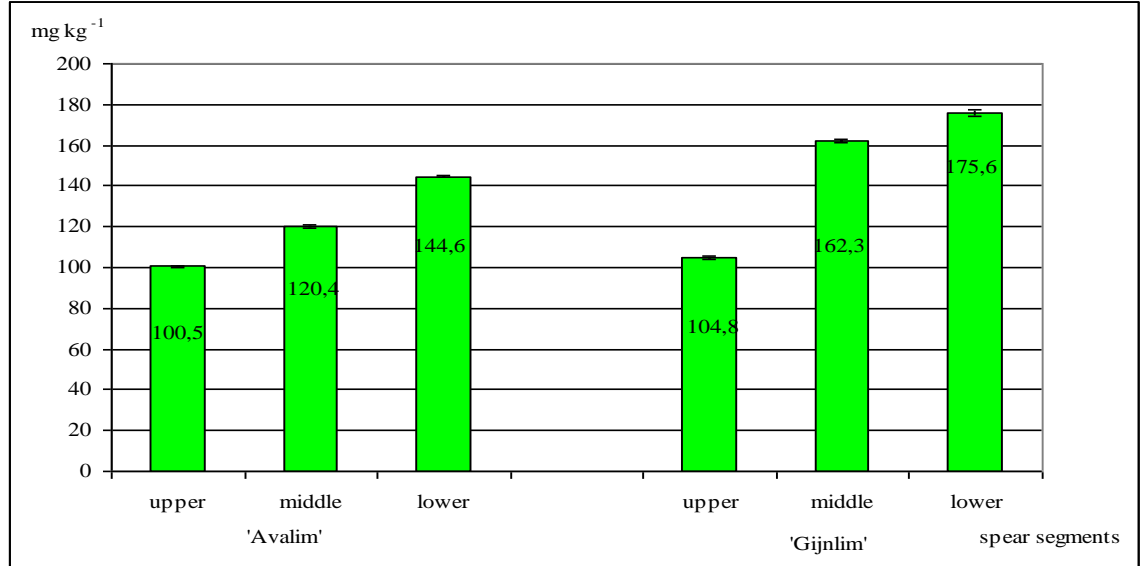

Figure 4. Nitrate content in different parts of asparagus spears, 2013-2014. 
Analysis of the study data showed that the fibre in different parts of asparagus spears has been cumulated in contrast comparing to vitamin $\mathrm{C}$ and dry matter cumulation results (Fig. 5). The highest fibre content is detected in the lower part of the spears. $16.8 \%$ of the fibre were defined in 'Avalim' spears, and $19.8 \%$ in 'Gijnlim' spears. The least fiber content was found in the upper part of the asparagus spears. 9.1\% of the fibre were in 'Avalim', and 9.7\% were assessed in the variety 'Gijnlim' spears.

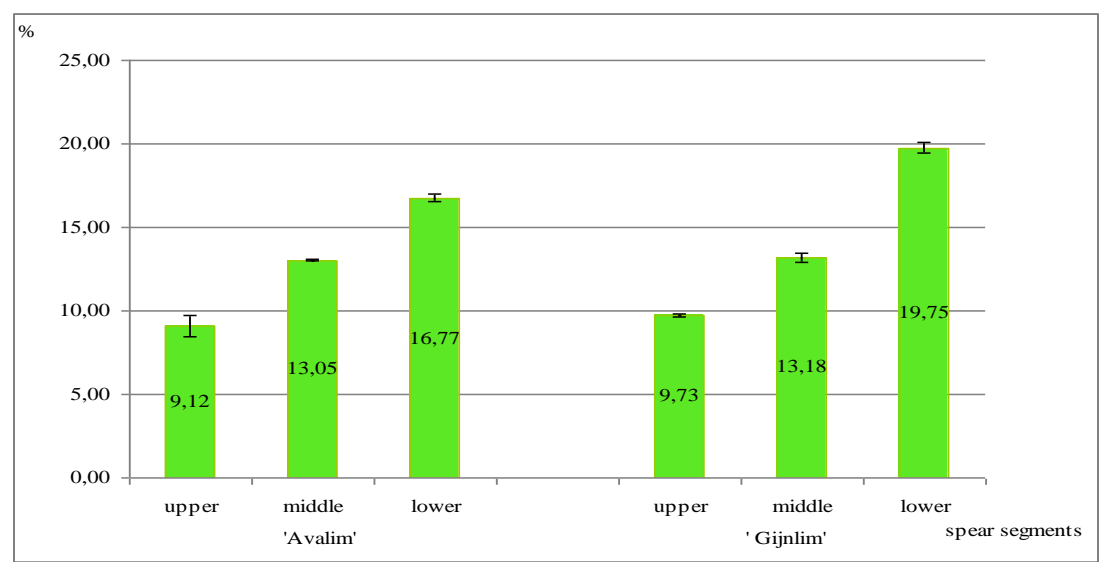

Figure 5. Fibre content in different parts of asparagus spears, 2013-2014.

Analysis of the test results showed that protein content varied in different parts of asparagus spears (Fig. 6). The highest amount of proteins was detected in the upper part of spears: $50.8 \%$ in variety 'Avalim', and 41.2\% in 'Gijnlim' variety spears. The lowest protein content was defined in the lower part of asparagus spears: $37.7 \%$ in 'Avalim' spears, and $23.6 \%$ in 'Gijnlim'.

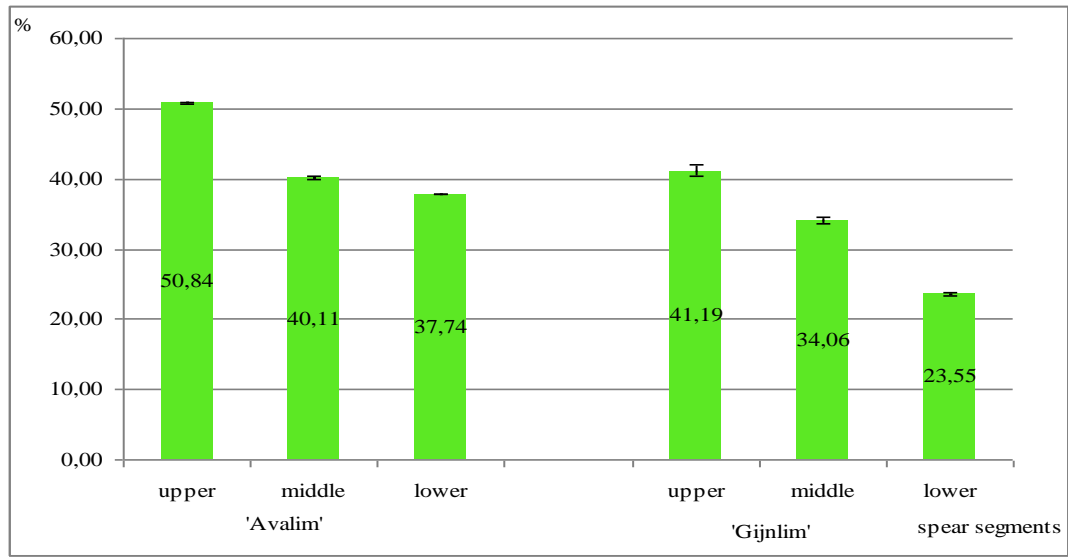

Figure 6. Protein content in different parts of asparagus spears, 2013-2014.

The study showed that the strength of asparagus spears was between 1.96 and $3.69 \mathrm{~N} \mathrm{~mm}^{-2}$ (Fig. 7). The lowest strength of the spears was observed in the lower and middle parts of the vegetable (from 1.87 to $2.13 \mathrm{~N} \mathrm{~nm}^{-2}$ ). The highest strength was found in the lower part of the spears of the variety 'Gijnlim'. The highest strength of 'Avalim' spears reached $3.19 \mathrm{~N} \mathrm{~nm}^{-2}$.

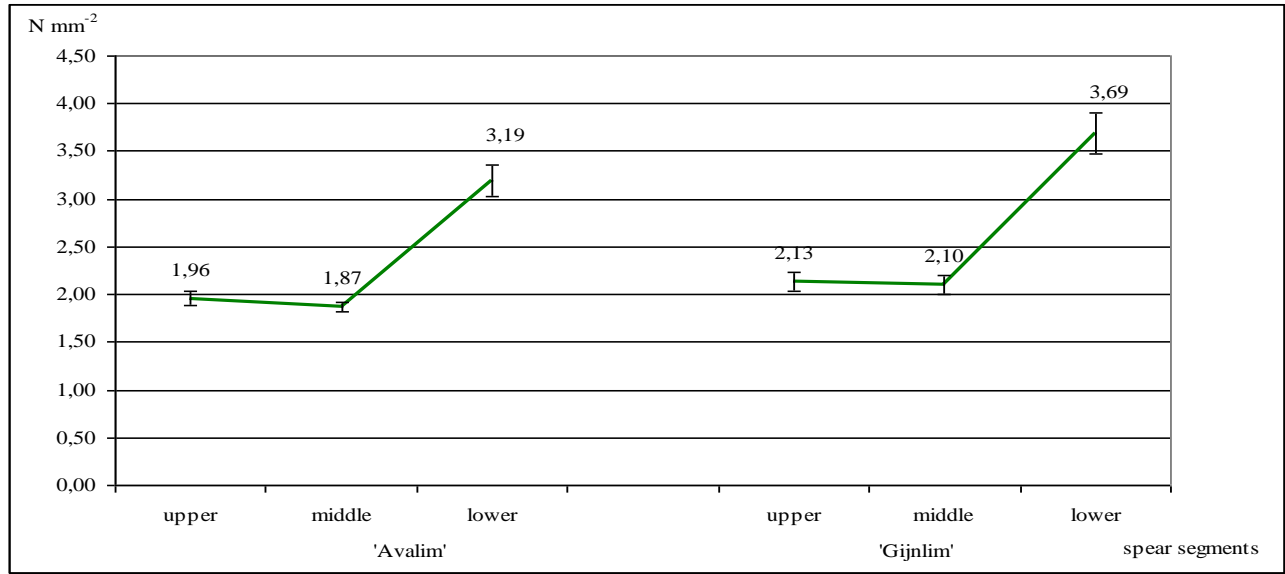

Figure 7. Strength of asparagus spears in different parts of the spear, 2013-2014. 
The hardness of fresh asparagus spears ranged from 9.65 to $23.60 \mathrm{~N} \mathrm{~mm}^{-2}$ (Fig. 8). The highest hardness was defined in the lower parts of the spears: in variety 'Avalim' it reached $22.51 \mathrm{~N} \mathrm{~mm}^{-2}$, and in 'Gijnlim' $-23.60 \mathrm{~N}-\mathrm{mm}^{-2}$. The lowest hardness was observed in the heads of the spears, i.e. in the upper parts of the spears.

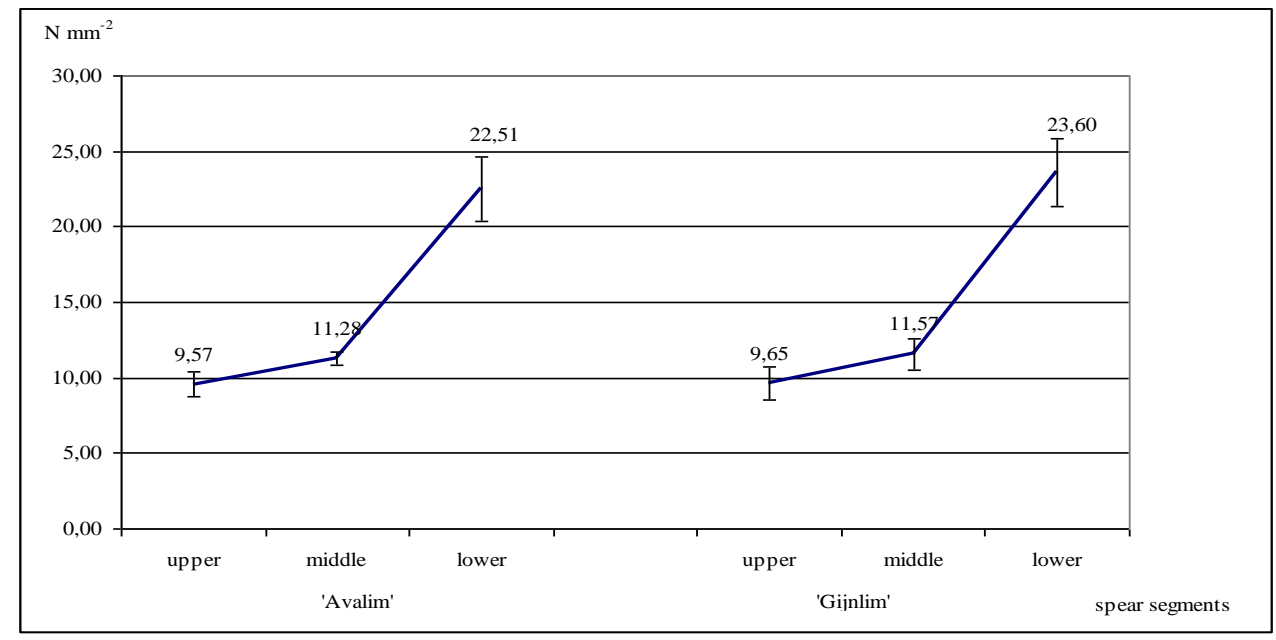

Figure 8. Hardness of asparagus spears in different parts of the spear, 2013-2014.

Comparing the results of the hardness study of two different asparagus varieties spears, the fact came out that spears of the variety 'Gijnlim' were slightly harder than the spears of the variety 'Avalim'.

The results of the study confirm the statements of some foreign scientists that the uneven amounts of mineral substances accumulate in different parts of the same plant and depend on the genotype of the plant and, particularly, on agrotechnical conditions (Yamaguchi, 1986; Evers, 2002).

\section{CONCLUSIONS}

1. The studies showed that the highest contents of vitamin $\mathrm{C}$, dry matter, potassium and protein and the lowest nitrate content were determined in the upper part of asparagus spears.

2. The largest content of fibre content was found in the lower part of asparagus spears.

3. The maximal strength and hardness of the spears were defined in the lower part.

\section{REFERENCES}

1. Chin, C. K., Garrison, S. A. 2008. Functional elements from asparagus for human health. Acta Horticulturae, Vol. 776, pp. 233-237. https://doi.org/10.17660/ActaHortic.2008.776.27

2. Januškevičius, E., Šerėnas, K., Vaičiulienė, O. 2005. Lietuvoje auginamų daržovių maistinè verte. Veterinarija ir zootechnika, Vol. 31, pp. 53. [In Lithuanian]

3. Januševičius, A., Mikulionienè, S. Pašaru tyrimo metodai ir pašaru maistingumas. Kaunas. 2004. 101 p. [In Lithuanian]

4. Kmitienè, L., Kmitas, A., Žebrauskienė, A. 2007. Evaluation of biological characteristics and productivity of introduced varieties of asparagus (Asparagus officinalis L.). Žemès ükio mokslai, Vol. 14, No. 4, pp. 33-40.

5. Kmitienė, L., Kmitas, A., Žebrauskienè, A., Klimas, E., Mikalauskiene, R. 2005. Evaluation of Biological Characteristics and Productivity of Introduced Varieties of Asparagus (Asparagus officinalis L.). Vagos, No. 69 (22), pp. 25-31.

6. LST EN 12014 - 7:2001: Maisto produktai. Nitratų ir (arba) nitritų kiekio nustatymas. 7 dalis. Nitratų kiekio nustatymas daržovėse ir jų produktuose, nitratus redukavus kadmiu. Tèkminis metodas = Foodstuffs-Determinationof nitrate and/or nitrite content - Part 7: Continuous flow method for the determination of nitrate content of vegetables and vegetable products after Cadmium reduction. Lietuvos standartizacijos departamentas. Vilnius. 2001, p.15. [In Lithuanian]

7. LST ISO 6557: Vaisiai, daržovès ir jų gaminiai. Askorbo rūgšties kiekio nustatymas. 2dalis. Iprastiniai metodai = Fruits, vegetables and derived products. Determination of ascorbic acid content. Part 2: Routine methods. Lietuvos standartizacijos departamentas. Vilnius. 2000, p.57. [In Lithuanian]

8. LST ISO 751:2000. Vaisių ir daržovių gaminiai. Vandenyje netirpių sausųjų medžiagų nustatymas. [In Lithuanian]

9. LST EN ISO 6865:2001. Pašarai. Žalios ląstelienos kiekio nustatymas. Tarpinio filtravimo metodas (ISO 6865:2000). Vilnius. Standartizacijos departamentas. [In Lithuanian]

10. Maeda, T., Kakuta, H., Sonod, T., Motoki, S., Ueno, R., Suzuki, T., Oosawa, K. 2005. Antioxidation capacity of extracts from green, purple, and white asparagus spears related to polyphenol concentration. HortScience, No. 40, p. 1221-1224.

11. Makus, D. J. 1994. Mineral nutrient composition of green and white asparagus spears. Hort Science, Vol. 29 (12), pp. $1468-1469$.

12. Miao Q., Hengjun j., Gerui R., Jianying H., Xiangyang W. 2012. Effect of chitosan coatings on postharvest green asparagus quality. College of Food Science and Biotechnology, Zhejiang Gongshang University, Hangzhou, China, 2027 p.

13. Oberbeil, K., Lentz, CH. 2004. Gamtos dovanoti vaistai. Kaunas. 263 p. [In Lithuanian] 
14. Rodkiewicz, T. 2008. Vitamin C changes and total antioxidant activity of fresh and stored green asparagus spears. Acta Horticulturae, Vol.776, pp. 235-238. https://doi.org/10.17660/ActaHortic.2008.776.29

15. Shalaby T. 2004. Genetical and nutritional influences on the spear quality of white asparagus (Asparagus officinalis L.). Disertation. Braunschweig, Federal Agricultural Research Centre (FAL). 126 p.

16. Shalaby, T.A. Dewir, Y.H. Haneklaus, S. Schnug, E. 2014. Weight loss and antioxidants degradation in spears of five asparagus cultivars during cold and freeze storage. Australian Journal of Crop Science, Vol. 8, pp. 397-401.

17. Tarakanovas, P.; Raudonius, S. Agronominių tyrimų duomenų statistinė analizè taikant kompiuterines programas ANOVA, STAT, SPLIT - PLOT iš paketo Selekcija ir Irristat. Akademija, 2003. p. 57. [In Lithuanian]

18. Weihua, L., Meijun, H., Yongsong, C., Huan, S.T.S., Xiwu, G., Daning, W. 2012. Determination of 20 Free Amino Acids in Asparagus Tin by High-Performance Liquid Chromatographic Method after Pre-Column Derivatization. Food Analytical Methods, Vol. 5, pp. 62-68. https://doi.org/10.1007/s12161-011-9197-1

19. Žebrauskienè, A., Paulauskienè, A., Abramavičienè, R. Investigation of Chemical Composition of Introduced Cultivars of Asparagus (Asparagus officinalis L.) Spears. Rural development 2013 : the sixth international scientific conference, Akademija : proceedings. Alesandras Stulginskis University, Vol. 6, b. 2, pp. 288-292 